\title{
Granulosa Cell Tumor
}

National Cancer Institute

\section{Source}

National Cancer Institute. Granulosa Cell Tumor. NCI Thesaurus. Code C3070.

A slow-growing, malignant tumor, characterized by the presence of granulosa-like cells and Call-Exner bodies, that is almost always found in the ovary. In rare cases, it has also been found in the testicle. There are two types of granulosa cell tumors that can be disting uished under the microscope: the adult and the juvenile. The testicular juvenile granulosa cell tumors are perhaps the most common congenital testicular neoplasms. 